\title{
TEMPOS DE BARBÁRIE: DA NECESSIDADE DE UMA NOVA ÉTICA AMBIENTAL
}

\author{
Ana Cristina Reis Cunha ${ }^{1}$ \\ Faculdade de Letras da Universidade de Lisboa (FLUL) \\ (D) https://orcid.org/0000-0003-2662-1166
}

\section{RESUMO:}

A escalada vertiginosa da atividade económica global, acompanhada do crescente desenvolvimento tecnológico, ameaça gravemente o equilíbrio ecológico do nosso planeta, pelo que urge alterar o paradigma de prosperidade até agora vigente. Torna-se necessário adotar uma nova ética ambiental. Trata-se do que designamos pela ética do 'cuidado', na qual não está em causa apenas a preocupação pela continuidade da espécie humana, que nos manteria numa visão antropocentrista, mas também o valor intrínseco da natureza. Há que superar o esquema 'sujeito-objeto', e isso faz-se quando o homem se vê como 'ser-no-mundo', como elemento constitutivo deste. Uma prosperidade sustentável implicará a alteração do paradigma da velha economia baseada no crescimento incessante e desenfreado, movida pela inovação e pela ânsia de ascensão social com base na posse de bens materiais. Os recursos limitados e a impossibilidade de absorção, por parte do planeta, dos efeitos nocivos do crescimento, obrigam-nos a refrear este crescimento selvagem com vista a assegurarmos o futuro da humanidade.

PALAVRAS-CHAVE: Ética ambiental; Prosperidade sustentável.

\section{TIMES OF BARBARISM: THE NEED FOR A NEW ENVIRONMENTAL ETHICS}

\begin{abstract}
:
The vertiginous escalation of global economic activity, accompanied by the increasing technological development, seriously threatens the ecological balance of our planet, so it is urgent to change our paradigm of prosperity. It becomes necessary to adopt a new environmental ethic. This is what we refer to as the ethic of 'care', in which concern is not only for the continuity of the human species, which would keep us in an anthropocentric view, but also the intrinsic value of nature. The 'subject-object' scheme must be overcome, and this is done when man sees himself as 'being-in-the-world', as a constituent element of this. A sustainable prosperity will imply the change of the paradigm of the old economy based on the incessant and unbridled growth, driven by the innovation and the anxiety of social ascension based on the possession of material goods. The limited resources and the inability of the planet to absorb the harmful effects of growth oblige us to curb this wild growth in order to secure the future of humanity.
\end{abstract}

KEYWORDS: Environmental ethics; Sustainable prosperity.

\footnotetext{
${ }^{1}$ Doutoranda em Filosofia na Faculdade de Letras da Universidade de Lisboa (FLUL), Portugal e colaboradora no CEFi, Centro de Estudos de Filosofia da Universidade Católica Portuguesa, anareiscunha@sapo.pt.
}

CUNHA, Ana Cristina Reis. Tempos de barbárie: da necessidade de uma nova ética ambiental. Griot : Revista de Filosofia, Amargosa, Bahia, v.16, n.2, p.67-80, dezembro/2017. 


\section{Introdução}

O paradigma adotado pela ciência galileana preconizou a completa inteligibilidade da natureza pelo homem e, consequentemente, o seu total domínio. Tudo se poderia reduzir a fórmulas matemáticas, pelo que tudo seria previsível e dominado pelo homem.

O desenvolvimento exponencial da técnica veio também conferir maior confiança ao homem, permitindo que este deixasse de se sentir indefeso face ao poder da natureza, que, anteriormente, se lhe afigurava enorme e misterioso. Contudo, os efeitos devastadores da ação do homem na natureza têm provocado respostas imprevisíveis por parte desta. Surgem tempestades em zonas do globo onde antes nunca se haviam verificado e em épocas do ano completamente inesperadas; os resíduos tóxicos e os acidentes nucleares estão na origem de deformações e doenças mortais que se registam ao longo de diversas gerações; a gigantesca poluição provocada pelo desregrado crescimento económico tem vindo a despoletar perigosas alterações climáticas, para citar apenas alguns dos gravíssimos problemas que assolam, hodiernamente, a humanidade.

Torna-se, pois, evidente que este tipo de comportamento, totalmente irresponsável, põe em causa a continuidade da espécie humana. Há, assim, nos dias de hoje, a consciência de que este estado de coisas tem de ser alterado e que o desenvolvimento só faz sentido se for sustentável, ou seja, se não comprometer as gerações vindouras.

A escalada vertiginosa da atividade económica global, acompanhada do crescente desenvolvimento tecnológico, ameaça gravemente o equilíbrio ecológico do nosso planeta, pelo que urge alterar o paradigma de prosperidade até agora vigente. Longe de se limitar aos prazeres materiais, a prosperidade consiste na capacidade de nos realizarmos enquanto seres humanos, e, para isso, são cruciais a saúde, a segurança, a liberdade de participação numa sociedade justa. $O$ desafio que temos de enfrentar consiste em alcançar tal propósito respeitando os limites ecológicos do nosso planeta, e, uma vez que os fenómenos naturais ignoram fronteiras, deveremos falar de uma ecologia integral.

Urge, pois, adotar uma nova ética ambiental. Trata-se do que designámos pela ética do 'cuidado', na qual não está em causa apenas a preocupação pela continuidade da espécie humana, que nos manteria numa visão antropocentrista, mas também o valor intrínseco da natureza. Há que superar o esquema 'sujeitoobjeto', e isso faz-se quando o homem se vê como 'ser-no-mundo', como elemento constitutivo deste. E é nessa relação com a natureza que o homem se depara com a superabundância do real, com aquilo que Leonardo Coimbra designa por 'excesso', ganhando especial sentido o referente da transcendência. Passa-se, então, de uma mundividência antropocêntrica para uma mundividência cosmocêntrica.

\section{Natureza e cultura}

\section{Animal laborans, homo faber e bios politikos}

A original análise que Hannah Arendt faz dos três tipos de atividade que são fundamentais para a condição humana permite-nos uma melhor compreensão das 
diferentes formas de intervenção do homem no mundo: o labor, que corresponde à vida biológica do homem como animal; o trabalho, que corresponde ao mundo artificial de objetos que o homem constrói; e a ação, que corresponde à nossa pluralidade como indivíduos diferenciados (ARENDT, 2001).

O labor corresponde ao desenvolvimento biológico do homem como organismo vivo. $\mathrm{O}$ homem é animal laborans, preso às necessidades fisiológicas com vista à sua sobrevivência, assim como à sobrevivência da sua espécie. Trata-se de uma atividade improdutiva. Os produtos do labor são rapidamente consumidos e destruídos, carecendo de durabilidade e estabilidade. O que o labor produz está, assim, destinado ao consumo, ou seja, à destruição, e o que for produzido em excesso apodrece.

Através do trabalho, uma atividade produtiva, ao contrário do labor, o homem emerge do domínio puramente biológico tentando dominar o mundo com a construção e produção de bens duradouros; é o homo faber. O trabalho confere permanência e durabilidade à fragilidade da vida humana, que nada deixa de palpável, de permanente, se o homem não construir artefatos que permanecerão para além da curta duração da sua vida. O homo faber é, assim, o homem do domínio, que impõe, com toda a soberania, a sua marca, a sua vontade.

A ação é a única atividade que se exerce diretamente entre os homens sem a mediação das coisas ou da matéria. É pela ação que o homem se diferencia dos restantes animais; pela ação o homem toma a iniciativa, introduz algo de novo no mundo, que, depois, é concluído por outros. É na ação propriamente dita que o homem se constitui como bios politikos. De entre as três atividades da vita activa, é, segundo a autora, a mais nobre, aquela que é suscetível de conferir sentido à existência humana, através da qual o homem pode alcançar a plenitude do seu ser, consubstanciando-se na interação pública através da praxis e da lexis.

\section{0 impacte ambiental das diferentes atividades humanas}

Pode-se dizer que, no vasto e variegado mundo da espécie animal, só o homem é ubiquitário, ocupando praticamente todas as regiões da Terra, mesmo as mais inóspitas, pelo que se confronta com meios muito diversos, que altera para satisfação das suas necessidades.

Este impacte que o homem exerce na natureza tem vindo a sofrer enormes alterações, desde os primeiros homens, que surgiram no Paleolítico superior, e que viviam na floresta como os animais, sem a alterarem de forma considerável, até ao homem atual, cuja ação tem, por vezes, um caráter que se pode considerar irreversível.

Na verdade, com a revolução tecnológica, houve uma mudança de paradigma na relação do homem com a natureza. A relação de fragilidade do homem com a natureza, que parecia dotada de uma força desconhecida e mesmo misteriosa, inverteu-se quando a técnica se desenvolveu exponencialmente, tornando frágil a natureza, uma vez que a ameaçou com uma agressividade devastadora.

Quer como animal laborans, que passou a explorar a Terra de forma extremamente agressiva, de que são exemplo as monoculturas destruidoras da biodiversidade, quer como homo faber, através do desenvolvimento industrial de

CUNHA, Ana Cristina Reis. Tempos de barbárie: da necessidade de uma nova ética ambiental. Griot : Revista de 
dimensões desproporcionais e sem regras, quer mesmo como bios politikos, na devastação do mundo através da violência, o homem põe em causa o seu futuro e o futuro do próprio planeta que habita. Num caso extremo de guerra em que sejam utilizadas armas nucleares, é a própria humanidade que pode vir a ser aniquilada.

\section{A ecologia e a bioética}

A consciencialização da importância da intervenção do homem na natureza fez com que surgisse uma nova ciência, a ecologia, e uma nova ética, a bioética, que, como veremos, não se confina à área da medicina.

Sendo a biologia a ciência do ser vivo, a ecologia, termo criado pelo biólogo alemão Ernst Haeckel, em 1866, e que provem etimologicamente de oikos, habitar, e logos, estudo, é a ciência que estuda as condições de existência dos seres vivos e as interações de toda e qualquer natureza entre estes e o seu meio.

Mais tarde, em 1935, Tansley, um botânico inglês, introduziu a noção de ecossistema para designar as interações energéticas e funcionais entre plantas e animais, ou biocenose, e o seu meio, ou biótopo. Biocenose e biótopo interagem para darem origem a um sistema organizado e funcional, o ecossistema (LAMY, 1996, p. 20). A ecologia é, assim, a ciência que estuda os ecossistemas.

Em tempos mais remotos, a natureza autoregulava-se e o homem era um mero espectador. Todavia, como atrás se salientou, o homem deixou de ser um espectador passivo, tendo-se convertido num transfomador ativo, um agente da evolução, colocando o problema ecológico a um outro nível, que já não é somente biológico, mas também ético, político, e até filosófico e teológico.

Surge, assim, uma nova ética. O termo 'bioética' foi utilizado pela primeira vez por Potter para designar a reflexão ética no exercício da medicina, mas tem agora um significado muito mais amplo, referindo-se aos problemas morais relativos à vida, que é inseparável da bioesfera.

\section{A barbárie na modernidade O mundo como objeto}

Entrámos, segundo Michel Henry, iniciador da fenomenologia da vida, num tempo de barbárie. Não se trata, infelizmente de mais uma crise da cultura, mas sim da sua destruição. $\mathrm{O}$ hiperdesenvolvimento de um hipersaber, cujos meios teóricos e práticos marcam uma rutura completa com os conhecimentos tradicionais da humanidade, pode destruir a própria humanidade. Com a explosão científica pode, assim, dar-se a ruína do homem. É esta a nova barbárie (HENRY, 1987, p. 10).

$\mathrm{O}$ ato inaugural e proto-fundador da ciência moderna consistiu na decisão tomada por Galileu de não considerar as qualidades sensíveis na investigação científica, que se centraria apenas nas qualidades primárias, quantificáveis, estudadas pela matemática e pela geometria. As chamadas propriedades secundárias foram excluídas precisamente por serem subjetivas. Deste modo, as afeções primeiras da relação do homem com o mundo foram afastadas, dando lugar a uma atitude idealizante. A ciência galileana caracteriza-se, então, pelo afastamento da subjetividade, ou seja, da vida, considerando que o mundo em que vivemos e que 
queremos compreender é constituído por corpos materiais extensos, pelo que será preciso pôr de parte os sentidos e aplicar os conhecimentos de geometria ao conhecimento desses corpos materiais. O mundo moderno crê que o único saber válido reside na física e nas ciências que lhe estão associadas; identifica saber com ciência.

Michel Henry alerta para o fato de a vida fenomenológica, ou seja, o que se vivencia a si mesmo, não poder ser estudada pela biologia, cujos algoritmos de nada valem para nos mostrarem o sentir de tudo o que sentimos e o sentirmo-nos a nós mesmos. A biologia considera o ser humano reduzido a partículas microfísicas. Confinada à visibilidade, a vida foi, deste modo, reduzida ao espaço da animalidade. Ora, o mundo não é um puro espetáculo que se oferece a um olhar impessoal e vazio, mas um mundo sensível; não é um mundo da consciência, mas um 'mundo-da-vida' (HENRY, 1987, p. 34).

Martin Buber, o iniciador da filosofia dialógica, apelida de 'eu-isso' o eu que lida com o mundo como se se tratasse de um mero objeto. Na verdade, há uma dualidade na atitude do homem perante o mundo, que se revela nas palavrasprincípio 'eu-tu' e 'eu-isso': “O mundo como experiência diz respeito à palavraprincípio EU-ISSO. A palavra-princípio EU-TU fundamenta o mundo da relação.” (BUBER, 2003, p. 6). Quando, por exemplo, experiencio uma árvore, ela permanece o meu objeto, a menos que, “... ao observar a árvore, eu seja levado a entrar em relação com ela; ela já não é mais um ISSO. A força de sua exclusividade apoderou-se de mim." (BUBER, 2003, p. 9). A árvore já não é mera impressão, mas apresenta-se 'em pessoa' diante de mim.

É importante notar, contudo, que a palavra-princípio 'eu-isso' não tem mal em si, uma vez que a matéria não tem nada de mal em si mesma. $O$ problema reside no fato de o homem ser dominado pelo eu da experiência e da utilização, e isso acontece quando o homem vive no mundo do isso. Como salienta Buber, o eu da palavra-princípio 'eu-isso' aparece como egótico e toma consciência de si como sujeito de experiência e de utilização, enquanto o eu da palavra-princípio 'eu-tu' aparece como pessoa, consciencializando-se como subjetividade (BUBER, 2003, p. 76). Ao contrário do experienciar e utilizar, na relação “... toca-nos um sopro da vida eterna" (BUBER, 2003, p. 73).

\section{O caráter irreversível da ação do homem}

A atitude que o homem tem vindo a adotar só pode, pois, ser considerada um contrasenso. Na verdade, como salienta Michel Henry, um modo de vida que se volta contra a vida, ou seja, contra si mesmo, é uma contradição (HENRY, 1987, p. 115). Leonardo Boff ${ }^{2}$ denomina esta catástrofe sócio-ambiental de ecocídio (PEREIRA, 2013, p. 112).

Esta atitude do homem perante a natureza, aliada ao exponencial desenvolvimento da técnica, desequilibrou, como já se viu, a relação de harmonia que anteriormente existia entre o homem e a natureza. Enquanto Aristóteles

\footnotetext{
2 Ecoteólogo e filósofo brasileiro conhecido por ter pensado a teologia da libertação e por ter participado na elaboração da Carta da Terra, datada de 2000.
}

CUNHA, Ana Cristina Reis. Tempos de barbárie: da necessidade de uma nova ética ambiental. Griot : Revista de 
considerava que a technë apenas modificava acidentalmente a natureza, sem alterar substancialmente a sua ordem, constatamos que, hoje em dia, já não é assim. Através da técnica atual o homem cria artificialmente coisas que a natureza não é capaz de produzir e disso são exemplo as substâncias químicas sintéticas que não existem de forma espontânea na natureza.

A alteração do paradigma na relação entre o homem e a natureza tornou-se bem visível com a descoberta da energia nuclear. Até então, o que os homens produziam podia ser por eles destruído e o que destruíam podia ser por eles reconstruído, mas isso deixou de se verificar com a energia nuclear. Hoje em dia, já não se pode falar em cavalos-vapor para definir a força das máquinas, como fez Watt relativamente à máquina a vapor, inspirando-se nos cavalos que moviam os moinhos na ausência de vento. A força produzida pela energia nuclear não tem equivalente na natureza. Daí dever-se falar do caráter irreversível da ação do homem.

Na origem da crise ecológica está, pois, o modo desordenado de conceber a vida (PAPA FRANCISCO, 2015, § 101) e a ação destruidora do ser humano. Podese, então, considerar que a crise ecológica se sedimenta na crise moral da sociedade. Como bem salienta Moltmann, a crise do mundo moderno não se deve apenas à tecnologia utilizada para depredar a natureza, nem ao desenvolvimento das ciências naturais, através das quais os homens se converteram em donos da natureza, mas fundamentalmente, à ânsia do homem pelo poder (MOLTMANN, 1987, p. 33).

\section{Uma nova ética ambiental: a ética do 'cuidado' Do antropocentrismo ao cosmocentrismo}

Na sua obra Das Prinzip Verantwortung: Versuch einer Ethik für die technologische Zivilization, de 1979, que se poderá traduzir para português por $O$ Princípio Responsabilidade: ensaio de uma ética para a civilização tecnológica, Hans Jonas apela à necessidade de uma nova ética, atendendo à transformação que se tem vindo a verificar na essência do agir humano.

Dotado das capacidades da linguagem, do pensamento e do sentido social, o homem constrói, invadindo a natureza, o artefato da cidade. $O$ homem é criador da sua vida, como vida humana, e vai submetendo as circunstâncias à sua vontade e consoante as suas necessidades. Exceptuando a morte, pode-se dizer que o homem nunca se encontra desprovido de recursos. Contudo, apesar de todas as suas capacidades inventivas, o homem sente-se pequeno face aos elementos da natureza. As suas incursões não afectavam, até à época hodierna, o equilíbrio da natureza. A natureza não era, assim, objeto da responsabilidade humana; a natureza cuidava de si mesma. Na verdade, as cidades floresciam e ruiam, as famílias prosperavam e caiam em desgraça, contudo, a natureza mantinha o seu equilíbrio e regenerava-se, mesmo após a intervenção do homem. Perante a natureza, não era necessário o uso da ética, mas da inteligência. Na cidade, ao contrário, a relação intrahumana tinha de ser regulada pela moralidade.

Falamos de uma época antropocêntrica, em que a ética se referia apenas às relações entre as pessoas. A ética referia-se ao 'aqui e agora'; havia uma aplicação imediata dos critérios éticos; disso são exemplo os mandamentos da narrativa bíblica. Toda a moralidade estava reduzida a este estreito campo de ação: a relação

CUNHA, Ana Cristina Reis. Tempos de barbárie: da necessidade de uma nova ética ambiental. Griot : Revista de 
entre os homens. Além disso, não era necessário ter qualquer conhecimento científico para que um ser humano soubesse como se deveria comportar em sociedade. É importante notar também que, para além da limitação espacial da ação do homem, ou seja, da limitação à envolvente próxima, o caráter bom ou mau da ação só se decidia num contexto imediato; ninguém era responsabilizado pelos efeitos posteriores dos seus atos bem intencionados.

Toda esta situação foi radicalmente alterada com a técnica moderna, impondo à ética uma nova dimensão de responsabilidade. A natureza, submetida à exponencial intervenção técnica do homem, apresenta agora uma enorme vulnerabilidade, que espelha bem a alteração registada na ação do homem sobre o meio ambiente. Surgiu, então, a ecologia, que estuda a interação do homem com o meio ambiente. Para garantir a sobrevivência da sua espécie, o homem tem, agora, de se tornar responsável pela natureza. O âmbito da ética tem, assim, de ser alargado, quer a nível espacial, quer a nível temporal. Na verdade, há que ter agora em consideração o equilíbrio de toda a bioesfera, mesmo no futuro remoto. Passou-se de uma ética antropocentrista para uma ética cosmocentrista. Na visão antropocentrista, o homem considerava-se um conquistador da natureza. Na visão cosmocentrista, procura-se o equilíbrio entre o homem e a natureza.

Cerqueira Gonçalves alertou, também, para a importância da adoção de uma nova mundividência, considerando que carecia de razão de ser a cisão entre o homem e o mundo, numa visão solipsista (GONÇALVES, 2014, p. 319), que o leva a agir como senhor do universo, tendo em conta apenas os seus interesses egoistas, sem atender a que, ao contrário do que defendia o chamado maniqueísmo ocidental, segundo o qual o homem era fonte exclusiva de sentido, é inerente a todo o real um sentido, pelo que o homem não pode ficar indiferente a ele.

As coisas do mundo são dotadas de consistência ontológica, como salientou Heidegger. Além disso, há uma profunda e intrínseca relação do ego com o mundo. Por isso, Heidegger define o homem como 'ser-no-mundo'. É importante notar, a este respeito, que 'ser-no-mundo' não tem um significado espacial de um ente que se encontra num lugar denominado 'mundo', mas sim que o homem não pode conceberse a não ser em relação essencial e constitutiva com o mundo. 'Ser-no-mundo' é uma estrutura unitária que constitui um modo de ser do homem; não tem um significado ôntico mas ontológico-existenciário. Por isso mesmo, Cerqueira Gonçalves salienta: "A superação da instância sujeito-objecto faz-se pelo enraizamento da vida do homem no solo do ser-no-mundo, passando a ser elemento constitutivo deste, numa harmonia de radical otimismo ontológico, onde se acentuam os termos positivos da relação, também constitutiva." (GONÇALVES, 2014, p. 323).

\section{Da necessidade de um novo imperativo}

Num planeta com recursos limitados e que já se encontra em risco de desequilíbrio ecológico, o grande desafio colocado à sociedade atual consiste, segundo Tim Jackson, em encontrar caminhos para a prosperidade sem crescimento (JACKSON, 2013). Para este conhecido economista ecológico britânico, professor de desenvolvimento sustentável na Universidade de Surrey, é crucial a alteração do paradigma de prosperidade, considerada pela maior parte dos economistas como 
estando necessariamente dependente do crescimento económico. Não se deverá esquecer, contudo, que há ainda milhões de seres humanos que se encontram abaixo do limiar da pobreza e que há locais no mundo em que nascem crianças apenas para morrerem de seguida, sem nunca terem sequer ingerido uma gota de água potável. $O$ fosso crescente entre poucos ricos, cada vez mais ricos, e muitos milhões de pobres, torna ainda mais gritante esta situação, em que o consumismo desenfreado, que se pode apelidar de doentio, das sociedades ditas desenvolvidas, está a delapidar os escassos recursos disponíveis.

$O$ grande desafio que agora enfrentamos consiste em encontrar um caminho para a plena realização do ser humano numa sociedade justa, na qual, face à limitação dos recursos existentes, terão de ser equacionadas, quer a redistribuição de bens, quer soluções inovadoras para suprirem, não só as necessidades de subsistência da humanidade, mas também as expectativas de cada um de nós em termos de realização como seres humanos. Trata-se de implementar o desenvolvimento sustentável.

O conceito de 'desenvolvimento sustentável' foi apresentado, pela primeira vez, em 1987, no Relatório Brundtland, designação pela qual ficou conhecido o documento intitulado Our Common Future, o nosso futuro comum, elaborado pela Comissão Mundial sobre o Meio Ambiente e o Desenvolvimento, criada em 1983 e liderada pela então primeira-ministra da Noruega, Gro Harlem Brundtland, e por Mansour Khalid. Entende-se por 'desenvolvimento sustentável' o processo através do qual as atuais gerações satisfazem as suas necessidades sem, no entanto, comprometerem a capacidade de as gerações futuras satisfazerem as suas próprias necessidades.

É de notar, contudo, que as primeiras referências ao desenvolvimento sustentável, se bem que não adotassem esta nomenclatura, começaram a surgir em 1972, durante a primeira conferência da ONU sobre o meio ambiente e o desenvolvimento, em Estocolmo, na Suécia, falando-se, então, de 'ecodesenvolvimento'.

$O$ início do debate internacional sobre o ambiente teve início, segundo defendem vários autores, em 1962, com a publicação do livro Primavera Silenciosa, de Rachel Carson. Seis anos mais tarde, em 1968, decorreu, em Paris, a Conferência Intergovernamental de Especialistas sobre as Bases Científicas para Uso e Conservação Racionais dos Recursos da Biosfera, organizada pela UNESCO e conhecida como Conferência da Biosfera.

Foi nesse mesmo ano, 1968, que se formou o Clube de Roma, dinamizado pelo então gestor da Fiat e da Olivetti, Aurelio Peccei. Constituído por empresários, cientistas e políticos, o Clube de Roma promove a discussão acerca dos limites do crescimento económico face à limitação dos recursos naturais existentes. Em 1972, e por iniciativa do Clube de Roma, foi publicado o estudo de um grupo de investigadores liderado por Dennis L. Meadows, intitulado "Os Limites do Crescimento", no qual se apela à necessidade de uma estabilidade ecológica e económica.

O debate ecológico não é, pois, recente, contudo, a humanidade está ainda longe da meta pretendida - a de um desenvolvimento sustentável, que não ponha em causa a sobrevivência das gerações futuras. Na verdade, tal não tem sido a clave sob

CUNHA, Ana Cristina Reis. Tempos de barbárie: da necessidade de uma nova ética ambiental. Griot : Revista de 
a qual têm vindo a crescer, desenfreadamente, as sociedades ditas desenvolvidas, com graves consequências para o equilíbrio da bioesfera.

Estando o homo faber na natureza do homo sapiens, o ímpeto da técnica atual fez com que surgisse um novo imperativo: conservar o mundo físico de forma a garantir a continuidade da espécie humana. Em substituição do velho imperativo de Kant, "Age de tal modo que a máxima da tua vontade possa valer sempre como princípio de uma legislação universal', Hans Jonas propõe, assim, um novo imperativo: "Age de modo que os efeitos da tua ação sejam compatíveis com a permanência de uma vida humana autêntica na Terra." (JONAS, 1995, p. 40). Ao contrário do imperativo de Kant, este dirige-se mais à política pública do que ao comportamento privado. Na verdade, sem o envolvimento dos Estados a nível global não será possível salvar o mundo, tanto mais que, tal como reconhece a Carta da Terra, publicada em 2000 em resultado de uma década de diálogo intercultural despoletado pela Organização das Nações Unidas, os objetivos de proteção ecológica, erradicação da pobreza, desenvolvimento económico equitativo, respeito pelos direitos humanos, democracia e paz são interdependentes. Por isso mesmo, Leonardo Boff, um dos autores da Carta da Terra, considera como princípios de uma nova ética de sustentabilidade, o princípio da afetividade, o princípio do cuidado, o princípio da cooperação e o princípio da responsabilidade (BOFF, 2006).

\section{0 retorno à metafísica}

\section{A evolução das atitudes intelectuais perante a natureza}

A forma como o homem se relaciona com a natureza depende, em grande parte, da sua atitude perante a mesma. Segundo Gracia Guillén, é possível distinguir, na filosofia ocidental, cinco atitudes distintas, a saber, a naturalista, a emotivista, a utilitarista, a racionalista e a realista (GRACIA GUILLÉN, 1991, p. 171).

A mais clássica é a atitude 'naturalista', que se encontra na origem da nossa cultura ocidental; a falácia naturalista afirma que a ordem da natureza é fonte direta da moralidade; bom é o que respeita a ordem da natureza. Para os gregos, o natural era sempre uno, verdadeito, belo e bom e o desnaturalizado era falso, feio e mau. Contudo, há fenómenos naturais, como os sismos e a doença, que não podem ser considerados bons, e cabe ao homem modificar a natureza, reordenando-a, de modo a que ela não seja meramente 'natural', mas 'racional'. Além disso, a razão humana é também uma faculdade natural e pode modificar a ordem da natureza, pelo que a fonte da moralidade não pode ser a natureza, mas a razão humana, construtora da ordem. A ordem tem de se fazer. Como refere o mesmo autor (GRACIA GUILLÉN, 1991, p. 174), a realidade não é um ordo factus mas um ordo faciendus, algo que se tem de construir, e cuja construção é um imperativo moral.

À atitude 'naturalista' seguiu-se a atitude 'emotivista'. A filosofia moderna criticou duramente a doutrina da objetividade das qualidades sensíveis. A fonte da moralidade não pode estar na ordem da natureza, uma vez que não podemos conhecer qual é essa ordem. A fonte da moralidade deve encontrar-se no interior do próprio homem. A natureza não tem uma ordem objetiva mas nós temos uma ordem subjetiva.

CUNHA, Ana Cristina Reis. Tempos de barbárie: da necessidade de uma nova ética ambiental. Griot : Revista de 
A atitude 'utilitarista', por sua vez, defende que as coisas não são boas na medida em que se ajustam a alguns princípios, mas em razão da sua utilidade. É interessante, ainda, notar que, para Hume, por exemplo, bem é a sensação subjetiva de bem-estar, pelo que um utilitarismo consequente não pode deixar de lado os animais, que também sentem. Todos os seres vivos capazes de sofrer entram no princípio do maior bem para o maior número e têm direito a que se tenha um comportamento ético para com eles. Daí que se possa falar dos direitos do animais. Com Peter Singer, o velho critério do maior bem para o maior número foi alterado: para que sejam verdadeiramente morais, as ações não devem ter em conta o maior número, mas todos. Foi, assim, alterado o princípio clássico do utilitarismo.

Enquanto a filosofia anglo-saxónica tendia para o emotivismo e o utilitarismo, a filosofia continental europeia pretendeu fundar a moralidade na pura razão. Trata-se da atitude 'racionalista'. Disso foi exemplo paradigmático Emmanuel Kant. O seu imperativo categórico pretende ser um ato puro de razão. A razão pura autofunda a sua própria moralidade, pelo que, para ele, era absurdo falar de moralidade a propósito dos animais. Os animais não são sujeitos de direitos, mas o homem tem deveres para com eles, assim como para com a natureza em geral.

$\mathrm{O}$ século XX inaugurou uma nova atitude, que se pode designar por 'realista' ou 'fenomenológica'. Foi a fenomenologia de Husserl que abriu um novo horizonte filosófico. A palavra de ordem da fenomenologia é a do retorno às próprias coisas. As vivências concretas constituem o ser egológico do cogito. Como já atrás se salientou, as coisas do mundo são dotadas de consistência ontológica. Isto tem consequências práticas muito importantes na forma como o homem encara o mundo, traduzindo-se naquilo a que Heidegger chama de 'cuidado' (Sorge), e que se revela crucial para a ecologia. A ontologia de Heidegger comporta, assim, uma ética. É interessante notar, a este respeito, que o ethos mundial proposto por Leonardo Boff, que se aplica ao âmbito planetário e não ao meramente humano, tem por virtude a ética do cuidado (PEREIRA, 2013, p. 110). O homem deve cuidar da natureza, dotada de consistência ontológica, reconhecendo, assim, o seu valor intrínseco.

\section{O valor intrínseco da natureza}

Face a esta situação nova, podemos interrogar-nos se a natureza terá um direito moral próprio, ou se devemos cuidar dela tendo em conta apenas o nosso interesse, mantendo-se, então, na base desta nova ética, a visão antropocêntrica anterior. Por isso mesmo, o filósofo e ecologista norueguês Arne Naess introduziu, em 1973, a expressão 'ecologia profunda' (PEREIRA, 2013, p. 27), em oposição ao que ele designava por 'ecologia superficial', ou seja, a visão tradicional que defende que o meio ambiente deve ser preservado tendo em conta apenas o interesse dos seres humanos. A ecologia profunda tem uma visão holística do mundo, que o concebe como um todo integrado, conferindo dignidade ontológica, quer ao ser humano quer à natureza. Esta valorização da natureza, da realidade sensível, foi, aliás, evidenciada por São Francisco, invocado pelo Santo Padre Francisco na sua mais recente Carta Encíclica “... como o exemplo por excelência do cuidado pelo que é frágil e por uma ecologia integral..." (PAPA FRANCISCO, 2015, § 10).

CUNHA, Ana Cristina Reis. Tempos de barbárie: da necessidade de uma nova ética ambiental. Griot : Revista de 
Faz sentido perguntarmos se o estado da natureza extrahumana, que se encontra agora submetida ao nosso poder, poderá ter um direito moral próprio. Isso implicaria que devessemos procurar, não só o bem humano, mas também o bem das coisas extrahumanas, incorporando no conceito de bem humano o cuidado com o mundo.

A natureza deve ser respeitada, tem uma dignidade própria. Excetuando a religião, nenhuma ética anterior nos preparou para esse papel de fiduciários, e muito menos a visão científica atual acerca da natureza, que a reduziu à indiferenciação de causalidade e necessidade. Como salienta Hans Jonas, da ameaçada plenitude do mundo da vida parece surgir uma surda chamada para o respeito pela sua integridade (JONAS, 1995, p. 35). Devemos escutá-la? Se o fizermos, estaremos a passar da doutrina da ação, isto é, da ética, à doutrina do ser, isto é, à metafísica, na qual toda a ética se deve fundar. O homem sente, assim, a necessidade de não ficar no plano moral, sendo remetido para o plano metafísico.

Vimos anteriormente que, com a idolatrização da ciência, a natureza se tornou um mero objeto da ciência e da técnica; contudo, as ciências positivas não revelam os mistérios que a natureza encerra. Para Foltz, o ser da natureza é-nos primordialmente revelado através do poético (FOLTZ, 2000, p. 191). Isso dever-se-á ao fato de, como defende Cerqueira Gonçalves, as três formas de racionalidade que é possível distinguir na cultura ocidental, o mito, a filosofia e a ciência, nunca serem completamente dissociáveis entre si (GONÇALVES, 1998, p. 19).

$\mathrm{Na}$ mundividência primitiva, a natureza encerra uma força genésica, enlaçando o homem em relações de geração, nascença, vida e morte. Esta força genésica não reside no homem; vem da Terra, da natureza; o homem reconhece-se como habitante do humus, sendo humilde ${ }^{3}$, porque não subsiste por si próprio. Será importante aqui recordar que o termo 'natureza' deriva do latim natura, que significa nascer, e que equivale ao termo grego physis, ou seja, crescer ou vir a ser. Há, pois, neste termo, a noção de dinamismo, um movimento que é intrínseco à natureza. Os pré-socráticos pensavam o mundo como um todo orgânico. $\mathrm{O}$ mundo era dominado internamente pelo poder da vida. É nesta linha que Aristóteles identifica physis com genesis; a natureza é animada de uma energia genésica. Aristóteles fala, mesmo, da alma do mundo. Foi ainda este filósofo da antiguidade que designou a natureza por ousia, substância ou essência, no seu sentido primitivo. A natureza é concebida como eterna, imutável e imperecível. Muito mais tarde, Santo Agostinho recupera esta ideia; 'natureza' significa essência, ser, substância, no sentido do que verdadeiramente é; Deus é natura naturans e o mundo é natura naturata, mas tudo é natureza. São Tomás recusou esta nomenclatura, que acusava de não fazer a distinção clara entre imanência e transcendência, tendo introduzido, com esse propósito, o termo analogia. É a analogia que permite a relação entre o homem e Deus. Constitui-se, então, uma hierarquia na realidade que deu a supremacia ao ser humano e que abriu o caminho para o antropocentrismo.

Nos tempos da modernidade e contemporaneidade, triunfou, como argumenta Américo Pereira, o dualismo cartesiano, em que o que não é humano é visto como mero instrumento, sem qualquer dignidade (PEREIRA, 2008, p. 14). Surgiu, então,

3 Termo que radica de humus.

CUNHA, Ana Cristina Reis. Tempos de barbárie: da necessidade de uma nova ética ambiental. Griot : Revista de Filosofia, Amargosa, Bahia, v.16, n.2, p.67-80, dezembro/2017. 
um segundo sentido de 'natureza', como o todo das coisas enquanto distinto do homem, que se caracterizou por uma nova forma de relacionamento do homem com a natureza, a da dominação.

Num terceiro significado de 'natureza', salienta Samuel Dimas, esta é entendida "... como o princípio interior a todos os entes e que os faz ser e agir. Neste sentido, a natureza de uma coisa é o que ela é na sua essência enquanto princípio de ação." (DIMAS, 2015, p. 9).

É neste último enquadramento conceptual que Lenoble apela a um regresso da metafísica: "Que o homem possa conceber a Natureza como um Todo é já um fato metafísico e uma afirmação da sua transcendência." (LENOBLE, 1990, p. 318)

\section{O sentido metafísico da natureza como Criação}

A Carta Encíclica Laudato $S i$ apela ao sentido metafísico da natureza como Criação. Trata-se de um texto de capital importância, que chama a atenção para a necessidade de uma ética, acompanhada de um enquadramento legal, não só para com o próximo, mas também para com o mundo.

Embora tenha uma linguagem de alguma forma antropocêntrica, a Bíblia chama a atenção para o cuidado com o mundo, a casa comum. É, pois, muito importante apercebermo-nos da contraposição entre dominar e cuidar, devendo o homem cuidar do mundo e comprazer-se com a contemplação da natureza que o rodeia.

A Carta Encíclica lembra o homem de que nunca se deve esquecer que Deus é o Pai Criador, pelo que não se pode considerar o dono e senhor do mundo. Nesse sentido, é mais importante falar em 'Criação' do que em natureza, pois a Criação só se pode conceber como um dom que vem de Deus. $O$ mundo não procede do caos, mas de uma decisão proveniente do amor de Deus, pelo que cada criatura tem um sentido na sua existência.

O pensamento judaico-cristão desmistificou, pois, a natureza, que deixou de ter um caráter divino, mas desmistificou também o homem, que não pode considerar-se o senhor do mundo. O homem deve, antes, colaborar com Deus na tarefa da Criação, uma vez que o mundo foi criado por Deus necessitado de desenvolvimento. $O$ mundo foi feito em aberto e não de uma forma acabada. $O$ encantamento do mundo deve-se, precisamente, a esta abertura radical. Neste enquadramento, "O fim último das restantes criaturas não somos nós. Mas todas avançam, juntamente connosco e através de nós, para a meta comum, que é Deus, numa plenitude transcendente onde Cristo ressuscitado tudo abraça e ilumina." (PAPA FRANCISCO, 2015, § 83). Todo o universo material é expressão do amor de Deus. A natureza revela o divino, e, no final dos tempos, Deus será tudo em todos; o natural ascederá ao sobrenatural.

Numa análise a esta Carta Encíclica, publicada na página do Secretariado Nacional da Pastoral da Cultura, João Paulo Costa refere que a importância deste texto é reveladora de que o discurso teológico, na sua dimensão antropológicocosmogenética e proto-escatológica, pode dar um contributo de grande relevância ao pensamento contemporâneo (COSTA, 2015). Salientando a influência que terá tido, na elaboração desta Carta Encíclica, o pensamento de Merleau-Ponty, que reabilitou

CUNHA, Ana Cristina Reis. Tempos de barbárie: da necessidade de uma nova ética ambiental. Griot : Revista de 
o sensível na intuição do tecido carnal, onde se dá a experiência originária do 'ser-nomundo", assim como o pensamento de Paul Ricoeur, que em Philosophie de la Volonté defende que o ser humano aprende a reconhecer-se a si mesmo na relação com as outras criaturas, o autor considera que o ponto chave heurístico e hermenêutico de Laudato $S i$ é a referência constante à interligação de todas as coisas: "Nunca é demais insistir que tudo está interligado." (PAPA FRANCISCO, 2015, §138). A este respeito, o filósofo e teólogo francês Emmanuel Falque, citado no mesmo artigo, considera que o cristianismo faz da totalidade do mundo um mundo da vida.

Laudato $S i$ mostra-nos que o mundo da vida tem uma dimensão antropológico-cosmológica, ou seja, ecológica, de casa comum, não sendo admissível uma atitude positivista de possessão objetal das coisas. Esta Carta Encíclica critica, de forma acintosa, o humanismo antropocentrista, que colocou o homem no centro do universo, fazendo com que o mundo da natureza se tornasse um mundo de objetos, e apela para a necessidade e urgência de o homem enveredar por um humanismo ecológico-teologal.

\section{Conclusão}

O humanismo criacionista desmistifica, como se viu, quer o homem, quer a natureza.

No objetocentrismo o homem cai numa egolatria consumista. Trata-se, segundo Galindo García, de uma visão moderna do teocentrismo medieval e do antropocentrismo renascentista (GALINDO GARCÍA, 1991, p. 116). Encontramos nestas sociedades um novo tipo de pobreza: a pobreza do 'ser', mais do que do 'ter'.

Uma prosperidade sustentável implicará, assim, a alteração do paradigma da velha economia baseada no crescimento incessante e desenfreado, movida pela inovação e pela ânsia de ascensão social com base na posse de bens materiais.

Os recursos limitados e a impossibilidade de absorção, por parte do planeta, dos efeitos nocivos do crescimento, obrigam-nos a refrear este crescimento selvagem com vista a assegurarmos o futuro da humanidade.

É necessária uma nova economia, mais solidária, mais justa, mais sustentável, mas possivelmente menos produtiva e menos lucrativa. Teremos, pois, de investir numa nova estrutura social, em que os valores não sejam os da posse e ostentação de bens materiais, mas antes os que conduzem à construção de uma sociedade sem grandes desigualdades, em que cada ser humano se possa realizar.

Galindo García salienta que é urgente e necessário criar um homem novo (GALINDO GARCÍA, 1991, p. 123). O homem tecnológico poderá dar origem ao homem lúdico, que, liberto pelas máquinas do trabalho produtivo, terá maior acesso à educação e a uma relação cuidadosa com a natureza. Por sua vez, do homem lúdico nascerá o homem criativo, que poderá desenvolver melhor as suas capacidades ao ver satisfeitas as suas necessidades e ao dispor, simultaneamente, de tempo livre para apreciar a natureza. Terá tempo para criar, sentindo-se mais realizado. Trata-se do homem valorizado pelo que é e pelo que faz e não pelo que tem.

${ }^{4}$ 'in-der-Welte- sein', de Heidegger.

CUNHA, Ana Cristina Reis. Tempos de barbárie: da necessidade de uma nova ética ambiental. Griot : Revista de Filosofia, Amargosa, Bahia, v.16, n.2, p.67-80, dezembro/2017. 


\section{Referências bibliográficas}

ARENDT, Hannah. A Condição Humana. Lisboa: Relógio d'Água Editores, 2001; BOFF, Leonardo. Ética e Sustentabilidade, Caderno de Debate, Agenda 21 e Sustentabilidade. Ministério do Meio Ambiente, Brasil, 2006;

BUBER, Martin. Eu e Tu. São Paulo: Centauro Editora, 2003;

COSTA, João Paulo. Laudato Si, entre relação, latência e complexidade, in Observatório da Cultura, $\mathrm{n}^{\circ}$ 22, www.snpcultura.org, 2015;

DIMAS, Samuel. Natureza e Ecologia. Texto de apoio à unidade curricular 'Ecologia e Filosofia do Ambiente' do Mestrado em Filosofia da Faculdade de Ciências Humanas da UCP, Lisboa, 2015;

FOLTZ, Bruce V.. Habitar a Terra: Heidegger Ética Ambiental e a Metafísica da Natureza. Lisboa: Instituto Piaget, 2000;

GALINDO GARCíA, Angel, Ecología y Desafío Ético, in AA.VV., O Cristão e o Desafio Ecológico. Coimbra: Publicações do ISET, Instituto Superior de Estudos Teológicos de Coimbra, 1991, pp. 95-125;

GONÇALVES, Joaquim Cerqueira, Em Louvor da Vida e da Morte: Ambiente - A Cultura Ocidental em Questão. Lisboa: Edições Colibri, 1998;

GONÇALVES, Joaquim Cerqueira. Itinerâncias de Escrita; Vol. III Escola/Ecologia, Lisboa: Imprensa Nacional- Casa da Moeda, 2014;

GRACIA GUILLÉN, Diego. Ecología y bioética, in AA.VV., Ética y Ecología. Madrid: Publicaciones de la Universidad Pontificia Comillas de Madrid, 1991, pp. 169-192;

HENRY, Michel. La Barbarie. Paris: Bernard Grasset, 1987;

JACKSON, Tim. Prosperidade sem Crescimento: Economia para um Planeta Finito, Lisboa: Edições tinta-da-china Lda, 2013;

JONAS, Hans. El principio de responsabilidad: Ensayo de una ética para la civilización tecnológica. Barcelona: Herder Editorial, 1995;

LAMY, Michel. As Camadas Ecológicas do Homem. Lisboa: Instituto Piaget, 1996;

LENOBLE, Robert. História da Ideia de Natureza. Lisboa: Edições 70, 1990;

MOLTMANN, Jürgen. Dios en la Creación: Doctrina ecológica de la creación. Salamanca: Ediciones Sígueme, 1987;

PAPA FRANCISCO. Louvado sejas: sobre o cuidado da casa comum. Prior Velho: Paulinas Editora, 2015;

PEREIRA, Américo. Oikos kai logos. Ecologia ou do sentido da morada terrena do homem., in www.lusosofia.net, 2008;

PEREIRA, Maurício Tavares, Novo Paradigma Civilizatório: Ética e Ecologia em Leonardo Boff. Dissertação de Mestrado em Filosofia apresentada na FAJE Faculdade Jesuíta de Filosofia e Teologia, sob a orientação do Prof. Doutor Carlos Roberto Drawin, Belo Horizonte, 2013.

Autor(a) para correspondência: Ana Cristina Reis Cunha, Faculdade de Letras da Universidade de Lisboa, Alameda da Universidade, 1600-214 Lisboa, Portugal. anareiscunha@sapo.pt

CUNHA, Ana Cristina Reis. Tempos de barbárie: da necessidade de uma nova ética ambiental. Griot : Revista de 